\title{
Postoperative Nausea and Vomiting - A Comparative Study between Palonosetron Vs. Ondansetron in Laparoscopic Cholecystectomies in a Tertiary Health Care Set Up
}

\author{
Joydeep Debnath ${ }^{1}$, Partha Debbarma ${ }^{2}$ \\ 1,2 Department of Anaesthesiology, AGMC, Agartala, Tripura, India.
}

\section{ABSTRACT}

\section{BACKGROUND}

Postoperative nausea and vomiting (PONV) are the most common complication seen following laparoscopic surgeries. We have conducted a study between two 5 $\mathrm{HT}_{3}$ antagonist palonosetron and ondansetron in patients undergoing laparoscopic cholecystectomies.

\section{METHODS}

A total of 180 patients, aged between 25-55 years, posted for elective laparoscopic cholecystectomies under general anaesthesia belonging to the American Society of Anesthesiologist (ASA), divided into one of two groups $(n=90)$, ASA- I \& II were included in the study. Before induction, patients in the first group (Group I) received $0.075 \mathrm{mg}$ palonosetron and patients in the second group (Group II) received $8 \mathrm{mg}$ ondansetron. Postoperatively, any incidences of early or delayed vomiting, requirement of rescue antiemetic, and side effects were recorded. Patient's hemodynamics were also monitored. Statistical analysis was done using Student's ttest, chi-square test, and Fisher's exact test.

\section{RESULTS}

Preoperative, intraoperative, and postoperative heart rate, mean arterial pressure, peripheral capillary oxygen saturation was statistically not significant $(p>0.050)$ in either group. In Group II, 16 patients had nausea in the first two hours and 6 patients had nausea in the two to six-hour postoperative period. In Group I, 6 patients experienced nausea in the first six hours period. 16 patients in Group II had vomited in the first two-hour period compared to 2 patients in Group I ( $\mathrm{p}=0.013$ ). The requirement of rescue antiemetic was greater in Group II than Group I (20\% vs. 4\%). No side effects were observed.

\section{CONCLUSIONS}

Palonosetron is more effective in treating PONV compared to ondansetron in patients undergoing elective laparoscopic cholecystectomies under general anaesthesia.

\section{KEY WORDS}

Postoperative Nausea and Vomiting, Palonosetron, Ondansetron, Laparoscopic Cholecystectomies.
Corresponding Author:

Dr. Joydeep Debnath,

Dhaleswar, Road No-9,

Agartala-799007,

Tripura (W), India.

E-mail: jdebnath797@gmail.com

DOI: 10.14260/jemds/2022/79

How to Cite This Article:

Debnath J, Debbarma P. Postoperative nause and vomiting - a comparative study between palonosetron vs. ondansetron in laparoscopic cholecystectomies in a tertiary health care set up. J Evolution Med Dent Sci 2022;11(03):410-414, DOI: 10.14260/jemds/2022/79

Submission 02-02-2017,

Peer Review 08-02-2022,

Acceptance 15-02-2022,

Published 21-02-2022.

Copyright (C) 2022 JEMDS. This is an open access article distributed under Creative Commons Attribution License [Attribution 4.0 International (CC BY 4.0)] 


\section{BACKGROUND}

Nausea and vomiting in the postoperative period occur in $20 \%$ to $30 \%$ of patients ${ }^{1}$ and together are the second most common complaints reported (pain is the most common). Postoperative nausea and vomiting (PONV) became the more commonly used clinical term; PONV can be such an unpleasant experience that patients often rate it worse than postoperative pain. Postoperative nausea and vomiting are the most common complication seen following laparoscopic surgeries. We have conducted a study between two 5 $\mathrm{HT}_{3}$ antagonist palonosetron and ondansetron in patients undergoing laparoscopic cholecystectomies. ${ }^{1}$

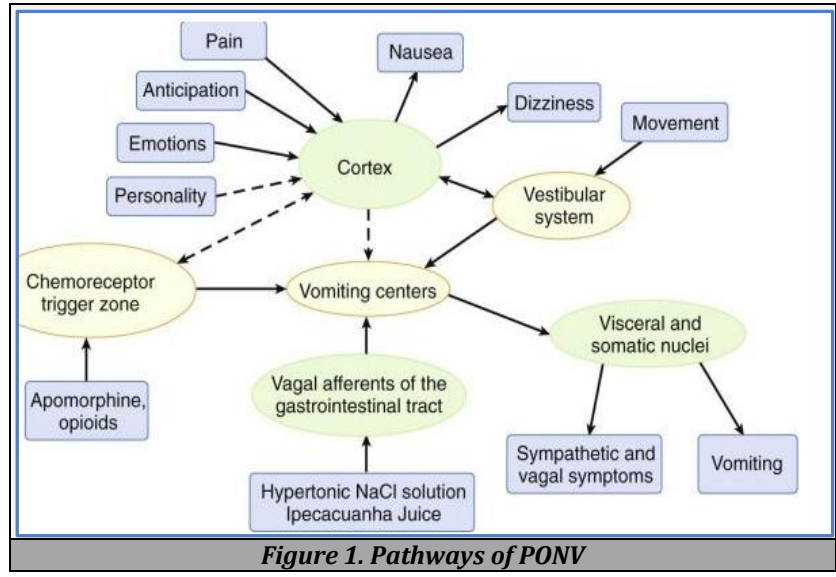

Diagrammatic summary of different trigger inputs for vomiting is shown above. The emetic coordinating circuitry is located within the medulla oblongata of the brain stem. The area postrema is thought to contain a chemoreceptor trigger zone for vomiting. Neurotransmitters and receptor subtypes of major importance for eliciting vomiting are indicated for various inputs

Despite the advances in anaesthetic and surgical techniques, PONV is still persistent. Various factors contributing to PONV include patient characteristics, anaesthetic technique, type of surgery, and postoperative care. $^{2}$ Women undergoing laparoscopic surgeries are particularly at risk. ${ }^{3}$

For this various pharmacological and nonpharmacological methods have been tried, but none has been 100 percent successful.4,5 The introduction of 5hydroxytryptamine 3 (5-HT3) receptor antagonists was a major advancement in the prevention of PONV because it had minimal side effects. Ondansetron is an example of a widelyused selective 5-HT3 receptor antagonist. ${ }^{6}$ Palonosetron is a recently introduced 5-HT3 receptor antagonist and has better antiemetic properties, and a 5-HT3 receptor binding affinity at least 30-fold higher than other 5-HT3 receptor antagonists. ${ }^{7}$

In the recent years there is no evidence that any dose of a single antiemetic can achieve more than $60-70 \%$ prevention of nausea and vomiting.8-11

Our study sought to compare the effectiveness of $0.075 \mathrm{mg}$ palonosetron ${ }^{12-16}$ with that of $8 \mathrm{mg}$ ondansetron ${ }^{17-21}$ for PONV in patients undergoing laparoscopic cholecystectomies. We also wanted to study the incidence of early or delayed vomiting, and the requirement of rescue antiemetics, and any side effects of these.

\section{Objectives}

Compare the effectiveness of palonosetron and ondansetron for post operative nausea vomiting.

\section{METHODS}

This randomized control, double-blind, prospective study was performed in AGMC \& GBP Hospital, Agartala, India, after obtaining the ethical committee clearance. Patients were randomized into two groups of 90 patients each according to the sealed envelope technique. Patients aged between 25-55 years old, ASA I \& II, who were posted for elective laparoscopic cholecystectomies under general anaesthesia were selected.

180 patients were divided into two groups by WINPEPI software where $Z \alpha=1.96, Z \beta=.84$. Variable permuted block randomization and single blinding (patient) was done.

\section{Exclusion Criteria}

Procedure refusal, receiving antiemetics, steroids, or psychoactive medications within 24 hours of study initiation, vomiting or retching in the 24 hours prior to surgery, having cancer chemotherapy within the last four weeks.

After taking proper informed consent, brief history and examination, patients were posted for surgeries. Patients were kept nil per os (NPO) for eight hours prior to surgery. All patients were given clonazepam tablet $(0.5 \mathrm{mg}$ orally) the night before surgery.

Patients basal heart rate (HR), mean arterial pressure (MAP), peripheral capillary oxygen saturation (SpO2) and electrocardiogram (ECG) were recorded. An intravenous line was secured with an appropriate size cannula, all patients were preloaded with $500 \mathrm{ml}$ lactated Ringer's solution over 30 minutes.

Patients were premedicated with glycopyrrolate $0.2 \mathrm{mg}$ intravenous (iv) injection and midazolam $1 \mathrm{mg}$ iv injection. Group I received $0.075 \mathrm{mg}$ palonosetron\& Group II received 8mg ondansetron before induction. All patients were preoxygenated for five minutes and were induced with anaesthesia and $2 \mathrm{mg} / \mathrm{kg}$ propofol and $0.8 \mathrm{mg} / \mathrm{kg}$ rocuronium to facilitate laryngoscopy and intubation. Oxygenation was continued by positive pressure mask ventilation followed by intubation.

Anaesthesia was maintained with nitrous oxide (N20), oxygen (02), sevoflurane, and controlled ventilation with the appropriate fresh gas flow. Analgesics were administered based on requirements. At the end of surgery, when patients had respiratory attempts, the residual neuromuscular blockage was reversed with neostigmine injection and glycopyrrolate. Recovery assessed and extubation was done after thorough throat suction. After complete clinical recovery, patients were shifted to the post-anaesthesia care unit.

The occurrence and severity of nausea and vomiting were assessed using the visual analogue scale (VAS) where a VAS score of zero indicated no nausea and a score of 10 indicated the most severe nausea. A four-point severity score was also used indicating no symptoms, mild nausea, severe nausea or 
up to two incidences of vomiting, and more than two incidences of vomiting. ${ }^{1}$ Rescue antiemetic drug use was monitored immediately after surgery at zero to two hours, two to six hours, six to 24 hours and more than 24 hours postsurgery.

An episode of vomiting was defined as either vomiting (expulsion of stomach contents) or retching (an involuntary attempt to vomit but not productive of stomach contents). Nausea was defined as a subjectively unpleasant sensation associated with awareness of the urge to vomit.1

Metoclopramide (10 mg iv injection) was used as a rescue antiemetic when two episodes of PONV occurred or for a VAS greater than five where the patient's requested treatment. A complete response was defined as the absence of PONV and no rescue antiemetic use.

Postoperative pain was treated with $75 \mathrm{mg}$ diclofenac intramuscular injection or $100 \mathrm{ml}$ paracetamol iv infusion.

Details of any adverse effects, including headache, dizziness, constipation, and myalgia, were recorded. The primary outcome measure of this study was the incidence of nausea and vomiting during the first 24 hours after anaesthesia and up to 48 hours.

Total of 180 patients were randomly assigned to receive either $0.075 \mathrm{mg}$ palonosetron or $4 \mathrm{mg}$ ondansetron. Patients in the two groups had a similar demographic profile, and no patients were later excluded from the study. Baseline hemodynamic data were also similar in both groups. Table 1 and 2 shows age distribution and duration of surgery in both groups.

\section{Statistical Analysis}

Statistical analysis was done using the Student $\mathrm{t}$ test, Fisher's exact test, and chi-square test with SPSS statistical software (SPSS Inc., Chicago, USA), version 17 and StatCalc software (AcaStat Software, USA). P-value was less than 0.05.

\section{RESULTS}

\begin{tabular}{|c|c|c|c|}
\hline & Mean Age & SD & p-Value \\
\hline Group -I & 38.8 & 8.5 & \multirow{2}{*}{0.478} \\
\hline Group-II & 36.1 & 8.8 & \\
\hline \multicolumn{4}{|c|}{ Table 1. Age Distribution in Group I and II } \\
\hline
\end{tabular}

The four-point severity score ${ }^{1,2}$ showed that in Group II, 16 patients had nausea in up to two hours after surgery compared to zero patients in Group I ( $\mathrm{p}=0.003) .6$ patients had nausea in the two to six hours period in both groups, which was not statistically significant. No patients had nausea after 24 hours.

\begin{tabular}{|c|c|c|c|}
\hline & Mean Duration (minutes) & SD & p-Value \\
\hline Group I & 125.7 & 23.8 & \multirow{2}{*}{0.712} \\
\hline Group II & 129.0 & 20.3 & \\
\hline
\end{tabular}

The four-point severity score ${ }^{1,2}$ showed that in Group II, eight patients had vomited up to two hours after surgery compared to one patient in Group I ( $\mathrm{p}=0.013)$. During the two to six hour and six to 24 hours postoperative period, seven patients in Group II had vomited compared to three patients in Group I ( $\mathrm{p}=0.179)$. None of the patients vomited after 24 hours.

\begin{tabular}{|c|c|c|c|c|c|c|}
\hline \multirow[t]{2}{*}{ Time (hours) } & \multicolumn{3}{|c|}{ Nausea } & \multicolumn{3}{|c|}{ Vomiting } \\
\hline & $\begin{array}{c}\text { Group } \\
\text { I }\end{array}$ & $\begin{array}{c}\text { Group } \\
\text { II }\end{array}$ & $\begin{array}{c}\text { p- } \\
\text { Value }\end{array}$ & $\underset{\text { I }}{\text { Group }}$ & $\begin{array}{c}\text { Group } \\
\text { II }\end{array}$ & $\begin{array}{c}\text { p- } \\
\text { Value }\end{array}$ \\
\hline $0-2$ & 0 & 16 & 0.003 & 2 & 16 & 0.013 \\
\hline $2-6$ & 6 & 6 & 1.000 & 6 & 14 & 0.179 \\
\hline $6-24$ & 0 & 0 & NA & 6 & 14 & 0.179 \\
\hline$>24$ & 0 & 0 & NA & 0 & 0 & NA \\
\hline
\end{tabular}

Rescue medication (10 mg metoclopramide iv injection) was given to $20 \%$ of the patients in Group II and only $4 \%$ of Group I patients. Side effects were not observed in either group.

\section{DISCUSSION}

Laparoscopic surgery has decreased the morbidity associated with cholecystectomy and has become an accepted procedure for symptomatic cholelithiasis.

Risk factors for nausea and vomiting after laparoscopic surgery include a long period of carbon dioxide insufflation, ${ }^{11}$ gall bladder surgery, ${ }^{10,12}$ female $\operatorname{sex}^{12}$ and postoperative use of opioids.

We have compared the effectiveness of palonosetron and ondansetron in alleviating PONV in patients undergoing laparoscopic cholecystectomy. Laparoscopic surgery was chosen because of the associated high incidence of PONV ${ }^{3-7}$. Factors affecting PONV include patient factors (age, sex, phase of menstrual cycle), anaesthesia-related factors (use of volatile agents, $\mathrm{N} 2 \mathrm{O}$, opioid), and surgery-related factors (middle ear surgeries, ophthalmic surgeries, abdominal surgeries). ${ }^{2} \mathrm{~A}$ higher incidence of PONV has been observed in female patients. ${ }^{2,3}$

The incidence of nausea in our study was $8.8 \%$ for Group I and $24.0 \%$ for Group II. 16patients in Group II had nausea in the first two hours postoperatively compared to no patients in Group I. During the two-to-six-hour period, 6 patients in both groups had nausea. No patients had nausea after six hours and up to 48 hours in either group.

Nausea and vomiting were more frequent in the first six hours postoperatively, observed by Pueyo et al. ${ }^{17}$ The same results were observed in the study done by Fujii et al. ${ }^{22} \mathrm{We}$ found the incidence of vomiting was statistically significant in the first two hours $(p=0.013)$ and not significant from then onwards. Rescue medication was also higher in Group II than Group I.

Our study suggests that palonosetron is better than ondansetron in preventing PONV, same results were found by Park JW et al. ${ }^{15}$

In our study, which was done within 48 hours of operative intervention, the loss of follow-up was almost nil since each patient was monitored on an hourly basis. However, whenever patients had nausea, rescue antiemetic was given, so we can assume that the three patients in the two-to-six-hour period were different from the 16 patients in zero to two hours period. The same assumption applies to the other hourly groups (six to 24 hours and more than 24 hours). 
It has been recommended to avoid nitrous oxide and minimizing concentration of the volatile anaesthetics in order to reduce the anaesthesia induced risk for PONV. ${ }^{23}$ We preferred using nitrous oxide in lower concentrations instead of avoiding it so that the concentration of volatile anaesthetic agent used did not exceed the minimal alveolar concentration (MAC) MAC value. ${ }^{1}$

We have studied palonosetron $0.075 \mathrm{mg}$ and ondansetron $8 \mathrm{mg}$, and found palonosetron is better than ondansetron whereas Mc Kenzie et al. (1994) and Candiotti et al. $(2008)^{24,25}$ studied with I.V. dose of ondansetron $4 \mathrm{mg}$ and I.V. palonosetron $75 \mu \mathrm{g}$. They also found palonosetron was better in comparison to ondansetron.

The comparative efficacy of palonosetron versus ondansetron has not been much demonstrated previously in laparoscopic cholecystectomy and mainly placebo has been used for comparison in clinical trials. ${ }^{25,26}$ However recently few studies have come up which have compared palonosetron with ondansetron and our results are also similar to them.

Majority of our results particularly the ones related to the incidence of nausea and vomiting may have been due to the difference in the duration of the two drugs. The statistical values were significant, especially in the 6-12 hrs period between both the groups.

How the efficacy of different 5 HT3 receptor antagonists vary is still unclear but most probably this difference may involve multiple factors such as intrinsic differences in 5 HT3 receptor blocking activity, 5 HT3 receptor affinity, binding stability and differences in autocrine activity of serotonin released from enterochromaffin cells to act on 5 HT3 or 5 HT4 receptors on EC.

To conclude, the result of the present study clearly indicates the facts that palonosetron has got a better antinausea effect, decrease in overall incidence of PONV, lesser need for rescue antiemetics postoperatively and a favourable side effect profile as compared to ondansetron in the postoperative $24 \mathrm{hrs}$ period thus, providing the patients with smooth convalescent period with lesser PONV, who undergo laparoscopic cholecystectomy surgery under general anaesthesia.

\section{CONCLUSIONS}

Palonosetron was more effective in preventing PONV compared to ondansetron in patients undergoing laparoscopic cholecystectomies under general anaesthesia. Rescue medication is also minimal in patients given palonosetron compared to those given ondansetron. Thus, palonosetron is an effective alternative to ondansetron in preventing PONV.

\section{Limitations}

- It was an active control comparison without a placebo group.

- Equipotent doses of palonosetron and ondansetron were not used; rather, optimal doses were used. Additional studies are needed to determine the equipotent doses of these drugs to prevent PONV.
- Pain intensity and additional analgesic medications were not assessed in this study, this may have affected the conclusions of the study.

\section{REFERENCES}

[1] Christian c. Apfel, Post operative nausea and vomiting, Chap- 86. In: Miller RD, Eriksson LI, Fleisher LA, et al. Millers anaesthesia. $7^{\text {th }}$ edn. Philadelphia, Churchill Livingstone 2010:2739-40.

[2] Gold BS, Kitz DS, Lecky JH, et al. Unanticipated admission to the hospital following ambulatory surgery. JAMA 1989;262(21):3008-10.

[3] Honkavaara P, Lehtinen AM, Hovorka J, et al. Nausea and vomiting after gynaecological laparoscopy depends upon the phase of the menstrual cycle. Can J Anaesth 1991;38(7):876-9.

[4] Habib AS, Gan TJ. Evidence-based management of postoperative nausea and vomiting: a review. Can J Anaesth 2004;51(4):326-41.

[5] Gan TJ, Diemunsch P, Habib AS, et al. Society for Ambulatory Anaesthesia. Consensus guidelines for the management of postoperative nausea and vomiting. Anesth Analg 2014;118(1):85-113.

[6] Culy CR, Bhana N, Plosker GL. Ondansetron: a review of its use as an antiemetic in children. Paediatr Drugs 2001;3(6):441-79.

[7] Rojas C, Stathis M, Thomas AG, Massuda EB, Alt J, Zhang J, et al. Palonosetron exhibits unique molecular interactions with the 5-HT3 receptor. AnesthAnalg 2008 Aug; 107(2):469-78.

[8] Aapro MS, Alberts DS. Dexamethasone as an antiemetic in patients treated with cisplatin. $\mathrm{N}$ Engl J Med 1981;305(9):520.

[9] Wang JJ, Ho ST, Liu YH, et al. Dexamethasone reduces nausea and vomiting after laparoscopic cholecystectomy. Br J Anaesth 1999;83(5):772-5.

[10] Rüsch D, Arndt C, Martin $\mathrm{H}$, et al. The addition of dexamethasone to dolasetron or haloperidol for treatment of established postoperative nausea and vomiting. Anaesthesia 2007;62(8):810-7.

[11] Bisgaard T, Klarskov B, Kehlet $H$, et al. Preoperative dexamethasone improves surgical outcome after laparoscopic cholecystectomy: a randomized doubleblind placebo-controlled trial. Ann Surg 2003;238(5):651-60.

[12] Maemondo M, Masuda N, Sekine I, et al; PALO Japanese Cooperative Study Group. A phase II study of palonosetron combined with dexamethasone to prevent nausea and vomiting induced by highly emetogenic chemotherapy. Ann Oncol 2009;20(11):1860-6.

[13] Blitz JD, Haile M, Kline R, et al. A randomized double blind study to evaluate efficacy of palonosetron with dexamethasone versus palonosetron alone for prevention of postoperative and postdischarge nausea and vomiting in subjects undergoing laparoscopic surgeries with high emetogenic risk. Am J Ther 2012;19(5):324-9.

[14] Ghosh S, Pal A, Acharya A, et al. Palonosetron and palonosetron plus dexamethasone to prevent postoperative nausea and vomiting in patients 
undergoing laparoscopic cholecystectomy: a prospective, randomized, double-blind comparative study. Anesth Essays Res 2011;5(2):134-7.

[15] Park JW, Jun JW, Lim YH, et al. The comparative study to evaluate the effect of palonosetron monotherapy versus palonosetron with dexamethasone combination therapy for prevention of postoperative nausea and vomiting. Korean J Anesthesiol 2012;63(4):334-9.

[16] Candiotti KA, Ahmed SR, Cox D, et al. Palonosetron versus ondansetron as rescue medication for postoperative nausea and vomiting: a randomized, multicenter, open-label study. BMC Pharmacology and Toxicology 2014;15:45.

[17] López-Olaondo L, Carrascosa F, Pueyo FJ, et al. Combination of ondansetron and dexamethasone in the prophylaxis of postoperative nausea and vomiting. $\mathrm{Br} \mathrm{J}$ Anaesth 1996;76(6):835-40.

[18] Rajeeva V, Bhardwaj N, Batra YK, et al. Comparison of ondansetron with ondansetron and dexamethasone in prevention of PONV in diagnostic laparoscopy. Can J Anaesth 1999;46(1):40-4.

[19] Thomas R, Jones N. Prospective randomized, doubleblind comparative study of dexamethasone, ondansetron, and ondansetron plus dexamethasone as prophylactic antiemetic therapy in patients undergoing day-case gynaecological surgery. $\mathrm{Br} J$ Anaesth 2001;87(4):588-92.

[20] Elhakim M, Nafie M, Mahmoud K, et al. Dexamethasone 8 $\mathrm{mg}$ in combination with ondansetron $4 \mathrm{mg}$ appears to be the optimal dose for the prevention of nausea and vomiting after laparoscopic cholecystectomy. Can J Anaesth 2002;49(9):922-6.

[21] Song JW, Park EY, Lee JG, et al. The effect of combining dexamethasone with ondansetron for nausea and vomiting associated with fentanyl-based intravenous patient-controlled analgesia. Anaesthesia 2011;66(4):263-7.

[22] Fujii Y, Saitoh Y, Tanaka H, et al. Ramosetron vs granisetron for the prevention of postoperative nausea and vomiting after laparoscopic cholecystectomy. Can J Anaesth 1999;46(10):991-3.

[23] Gan TJ, Meyer T, Apfel CC, et al. Consensus guidelines for managing postoperative nausea and vomiting. Anesth Analg 2003;97(1):62-71.

[24] Candiotti KA, Kovac AL, Melson TI, et al. A randomized, double blind study to evaluate the efficacy and safety of three different doses of palonosetron versus placebo for preventing postoperative nausea and vomiting. Anesth Analg 2008;107(2):445-51.

[25] Ray McKenzie R, Tantisira B, Karambelkar DJ, et al. Comparison of ondansetron with ondansetron plus dexamethasone in the prevention of postoperative nausea and vomiting. Anesth Analg 1994;79(5):961-4.

[26] White PF, O'Hara JF, Roberson CR, et al. Impact of current antiemetic practices on patient outcomes: a prospective study on high-risk patients. Anesth Analg 2008;107(2):452-8. 